\title{
Characteristics of Sediments Deposition in Karimata Strait
}

\author{
Muhammad Trial Fiar Erawan ${ }^{1 *}$, Tri Prartono ${ }^{2}$ and Ali Arman ${ }^{3}$ \\ ${ }^{1}$ Marine Science Study Program, Bogor Agricultural University \\ 2Marine Science Department, Bogor Agricultural University \\ Jl. Rasamala, Kampus IPB Darmaga Bogor 16680Indonesia \\ ${ }^{3}$ Center for Radiation and Isotope Application, National Nuclear Center of Indonesia \\ Jl. Raya Lebak Bulus, No. 9 Jakarta Selatan 12070 Indonesia \\ Email: fiarerawan90@gmail.com
}

\begin{abstract}
Karimata strait connects South China Sea and Indonesia territorial seas where the strait current pattern is affected by west and east monsoon. This condition influences particles depositing sedimentation process in the strait. Lack information about sediment depositing rate at the straits dozens years ago makes this research is important to be conducted. This research was to estimate sediment depositing rate in the strait in two areas, near shore and off shore of Borneo. The research was conducted on June to September 2015 used coring sediment samples. Those samples were derived from Baruna Jaya VIII Ship Cruise on June 2015 that was collaborative research between Ministry of Marine and Fisheries Affairs of Indonesia and National Nuclear Center of Indonesia (BATAN).Samples were analyzed in the laboratory of Chemical and Ocean, Department of Environmental and Natural Resources, Center of Radiation and Isotope, National Nuclear Center of Indonesia (BATAN). Estimation of sediment depositing rate used natural isotope ${ }^{210} \mathrm{~Pb}$. The study shows that the depositing rate of the nearest to Borneo area is about $0.92 \mathrm{~kg} \cdot \mathrm{m}^{-2} \cdot \mathrm{y}^{-1}$ (1965) and increases to be $3.31 \mathrm{~kg} \cdot \mathrm{m}^{-2} . \mathrm{y}^{-1}$ (2009). The other area is about $0.08 \mathrm{~kg} \cdot \mathrm{m}^{-2} \cdot \mathrm{y}^{-1}(1840)$ and increases to be $1.78 \mathrm{~kg} \cdot \mathrm{m}^{-2} \cdot \mathrm{y}^{-1}$ (2010). This result implies that the sediment depositing rate at the nearest area to Borneo is higher than the off shore.
\end{abstract}

Keywords: Near shore, off shore, Natural Isotop ${ }^{210} \mathrm{~Pb}$, CRS (Constant Rate of Supply) model

\section{Introduction}

Karimata strait is a part of Sunda Exposure and included into shallow water categorized as $<85$ $m$ depth. This strait connects South China Sea and Indonesia territorial seas such as Java Sea, Sunda Strait, Flores Sea, Banda Sea and Makassar Strait (Gordon et al., 2003). Bottom deposition at the exposure consists of some type of sediments and quarters which come from lands, beaches, rivers, alluvial deltas, swamps, kaolin clays of weathering bottom rocks and volcanic muds. Water current at the strait moves from Southeastern to the Northern until Northwestern on East monsoon and adversely, on West monsoon, the current moves dominantly to South-Southeast of the strait (Situmorang and Andi, 1999). This condition affects to sediment particles depositing process. Sediment transport is highly related to the amount of energy that drives those particles and the internal function of the particles (Rifardi, 2012). Hence, the areas have low energy transport resulting sediment particles depositing faster than the high energy transport.

Study on age and sediment deposition rate can be carried out by using radio isotope that has been applied for many years either ${ }^{14} \mathrm{C}$ or natural isotope ${ }^{210} \mathrm{~Pb}$. However, ${ }^{14} \mathrm{C}$ seldom applies to geological aspects of knowledge which has study age is more than 150 years of age. In addition, the natural isotope ${ }^{210} \mathrm{~Pb}$ is applied in the span of 150 years. Goldberg (1963) was the first scientist who developed geo-chronological study using natural isotope ${ }^{210} \mathrm{~Pb}$, including sediment accumulation from its stratigraphy.

Usage of natural isotope ${ }^{210} \mathrm{~Pb}$ is very suitable for studying environmental changes where human activities begins to impact on the environment (Lubis et al., 2007).The existence of natural isotope ${ }^{210} \mathrm{~Pb}(\mathrm{~T}$ $1 / 2=22.23 \pm 0.12$ year)comes from two process; (1) ${ }^{226} \mathrm{Ra}$ decays to form gaseous ${ }^{222} \mathrm{Rn}$ that mixes in the open air to forming unsupported ${ }^{210} \mathrm{~Pb}$. Furthermore, the unsupported ${ }^{210} \mathrm{~Pb}$ enter down to the water, then to bind with suspended particles and gravitate together with forming sediment layers. (2) ${ }^{226} \mathrm{Ra}$ decays in the sediment is being a supported ${ }^{210} \mathrm{~Pb}$. ${ }^{210} \mathrm{~Pb}$ activity within the sediment core layers drops with the sediment depth, and it can figure out the age and sediment depositing rate in span of 150 years long. Furthermore in many cases, it explains sediment depositing rate variedly as many years 
(Appleby and Oldfield, 1978). Therefore, there is important to conduct a research which relates to sediment depositing rate in the Karimata strait.

This research was aimed to estimate sediment deposition rates at Karimata strait, near shore and off shore of Borneo that occurs since years ago.

\section{Materials and Methods}

The sediment samples used were the cruise samples in the Karimata Strait (Figure 1) with using research vessel Baruna Jaya VIII by Ministry of Marine and Fisheries Affairs in cooperation with National Nuclear Center of Indonesia. Sampling sediment cores coordinates geographically were Station 1 (108'32'49.5"E; $1^{\circ} 54^{\prime} 6.48^{\prime \prime}$ ) and Station 2 (10903'48.8"E; $1^{\circ} 24^{\prime} 05.3$ "S). Those sediment samples then were analyzed in the Laboratory of Chemical and Phisical, Department of Natural Resources and Environment, Radiation and Applied Isotope Center, National Nuclear Center of Indonesia (BATAN).

Consideration of determining location were distance of main inputs of sediment particle resources and oceanographic condition such sea water current speeds and patterns (INDESO, 2015). Sampling coordinate at Station 1 represented off shore areas with $40 \mathrm{~m}$ depth of water and $28 \mathrm{~cm}$ width of samples, and the water current of this area is high. Whilst other sampling area, Station 2 represented areas nearest to Western Borneo with $27 \mathrm{~m}$ sample depth of water and $5 \mathrm{~cm}$ width of sample. The nearest area to Borneo is fathomed as main source of sediment particles entering to the water through existing rivers. Sampling sediments in the research location used box core with dimension $50 \times 50 \times 40 \mathrm{~cm}$ at certain depths. Sediments in the box core were taken by using PVC pipe, then those samples were breezing in to a refrigerator (administrating during the vehicle cruise). Furthermore, those coring samples were transported to the laboratory and stored in a freezer before preparation and analysis.

Sediment samples were cut in $1 \mathrm{~cm}$ long from surface until $10 \mathrm{~cm}$ depth and then $2 \mathrm{~cm}$ long after using plastic knives to avoid heavy metals contamination at the sediment coring. Those cut samples then were weighed both wet and dried masses weight. This weight aimed to determine water content in the sediment. Those dried samples then crushed using mortar to be fine. Drying sample using oven with temperature $60^{\circ} \mathrm{C}$ for $24 \mathrm{~h}$ (Sanchez-Cabeza et al., 1999; IAEA-TECDOC 1360, 2003; Lubis, 2008).

Total activity of $210 \mathrm{~Pb}$ was determined by the resulting measurement of ones its decay such as ${ }^{210} \mathrm{Po}$ with assuming that there is a balancing between them. Destruction briefly of samples followed Sanchez-Cabeza (1999) sifthing sediment samples were taken 4-5 g pouring into a beaker and it was administered with standard solvent ${ }^{209} \mathrm{Po}$ about $0.4 \mathrm{ml}$ as tracer, added 10ml HCL (1:1), 10ml $\mathrm{HNO}_{3}(1: 1), 15 \mathrm{ml} \mathrm{H} \mathrm{H}_{2} \mathrm{O}$ and 5 drops $\mathrm{H}_{2} \mathrm{O}_{2} 30 \%$, then those sample were heated until dried using waterbath (temperature $80^{\circ} \mathrm{C}$ ). Adding $10 \mathrm{ml} \mathrm{HCL}$ solvent (1:1) and $40 \mathrm{ml} \mathrm{H}_{2} \mathrm{O}$ to those samples. It were heated as long as 10 mins, then filtered using Whatman filter number 42 . Filtrated samples were

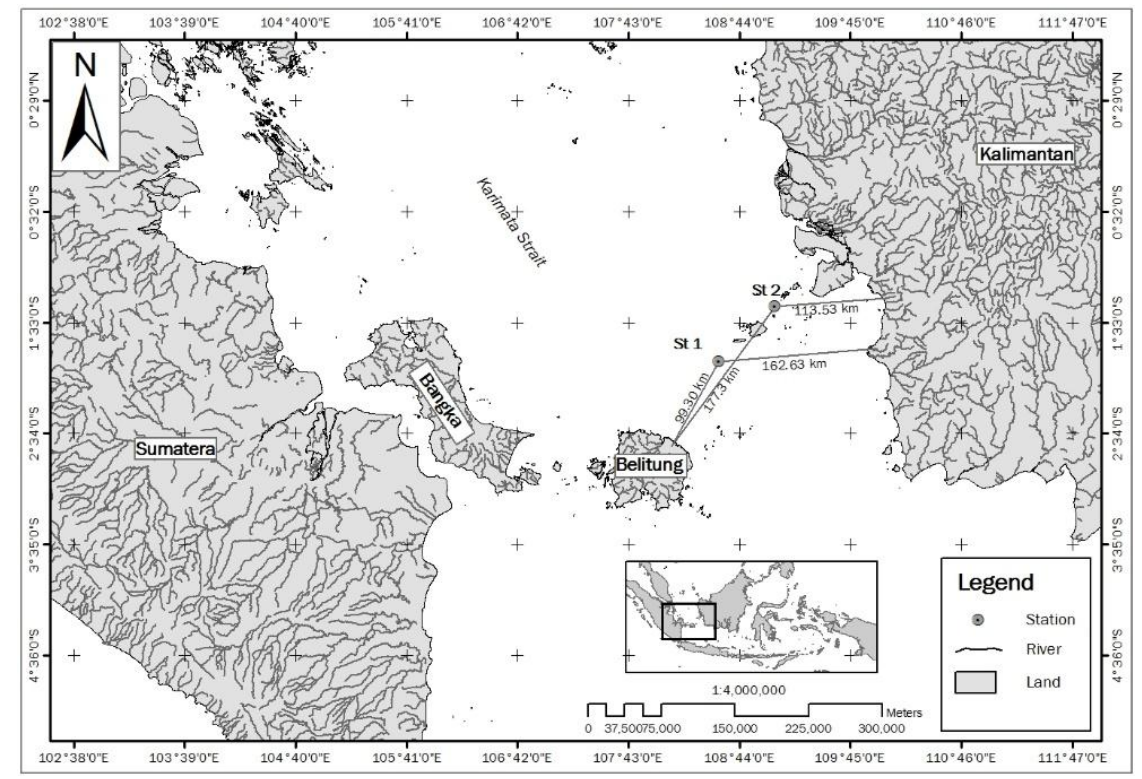

Figure 1.Location of Sediment Core at Station 1 and 2 
dried to be formed deposits. It were added with $4 \mathrm{ml}$ HCL (1:1) and stired using porcelain spoon and its volume was assigned as much as $100 \mathrm{ml}$ by adding HCL $0.3 \mathrm{~N}$. Those sediment samples were taken as much as $50 \mathrm{ml}$ and then it were appended with 400 $\mathrm{mg}$ of ascorbat acid. Furthermore, this solution was heated for \pm 5 mins and well stirred for $\pm 2 \mathrm{~h}$. This sample then was minced using Alpha spectrometer produced by Canberra with PIPS (Passiveted Implanted Planar Silicon) detector (A450-20AM). This tool works at rosolution $20 \mathrm{keV}$ in vacum condition. The minced process was conducted for \pm 4 $\mathrm{h}$.

Measuring background at Alpha spectrometer was carried out at the same periode and its results were diminshed on the result of sample measurment. Sediment ages and accumulation rates were determined by using CRS (Constant Rate of Supply) model. This model is practicable to count ages and accumulation rates of sediment and it has seldom applied by scientists (Ballestra and Hamilton, 1994; Sanchez-Cabeza et al.,1999; Hancock and Hunter, 1999; Lubis 2006). This model was recomended by Krishnaswamy et al. (1971) and Golberg (1963) first introduced the CRS model capable of calculating sedimentation ages in sedimentary layers. This model requires an unsupported ${ }^{210} \mathrm{~Pb}$ value in sediment layers. Value $\mathrm{A}$ is gained from alleviating total of unsuported ${ }^{210} \mathrm{~Pb}$ and value of unsupported ${ }^{210} \mathrm{~Pb}$ at depth $\mathrm{x}$, and $\mathrm{k}$ is a radioactive decay constant of $210 \mathrm{~Pb}=0,03114$.year $1, A(0)$ is a sum of unsupported ${ }^{210} \mathrm{~Pb}$ at a total cores (Bq. $\mathrm{m}^{2-1}$ ). Furthermore, $\mathrm{t}$ is sediment age (year) where is gained (Appleby and Oldfield, 1978). Sediment depositing rate in each unit of time, $r$ is a sediment depositing rate $\left(\mathrm{kg} \cdot \mathrm{m}^{-2}\right.$ year ${ }^{-1}$ ) (Willard and Holmes, 1997), and $\mathrm{C}$ is an unsupported constratetion of ${ }^{210} \mathrm{~Pb}$ at $\mathrm{x}$ depth (Bq. $\left.\mathrm{kg}^{-1}\right)$.

\section{Results and Discussion}

\section{Total activity of $210 \mathrm{~Pb}$}

Total activity profile of ${ }^{210} \mathrm{~Pb}$ in each coring (Figure 2.) shows that the sediment surface undergoes clearly fluctuation. This is caused by sediment particel mixed as a result of stirring process in the sediment surface. Total activity value of ${ }^{210} \mathrm{~Pb}$ is acquired at the Station 1 is about 10.218 Bq.kg-1 (layer 17-19 cm) - 92.610 Bq.kg-1 (layer 1-2 $\mathrm{cm}$ ) and Station 2 is about 53.980 Bq. kg-1 (layer 4-5 cm) 74.828 Bq. kg-1 (layer 0-1 cm). In a common, the total activity of $210 \mathrm{~Pb}$ indicates the decrease with increasing depth. This decrease is caused by radioactive decays of ${ }^{210} \mathrm{~Pb}$ to time. Jeter (2000) stated that this matter can be leaded by the deeper layer in a coring show very old time, so that radioactive decay is assumed as indication of decreasing concentration to depth.

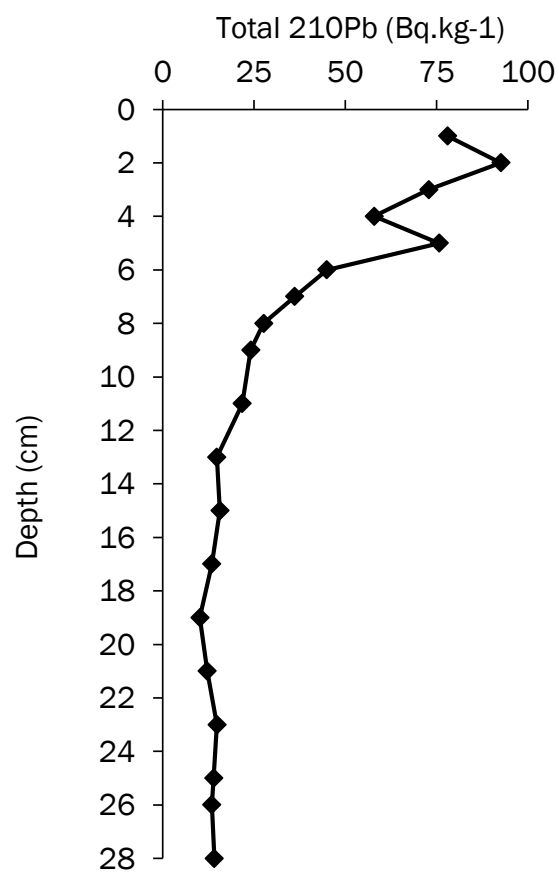

Total 210Pb (Bq.kg-1)

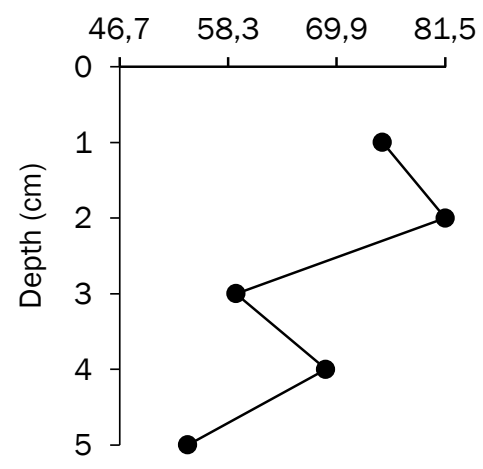

Station 2

Station 1

Figure 2. Profile of total activity ${ }^{210} \mathrm{~Pb}$ towards depth of sediment coring samples of Karimata Strait 


\section{Profile of sediment ages}

Determining sediment dating was achieved from applying CRS model. The acquired bottom core sediment level is determined using natural isotope $210 \mathrm{~Pb}$ at both areas, Station 1 and Station 2 (Figure 3$.$) , are layer 9-11 \mathrm{~cm}$ (175 years old) and layer 3$4 \mathrm{~cm}$ (50.4 years old). Sediment core deposited forming year that is derived at St 1 on layer $9-11 \mathrm{~cm}$ and $0-1 \mathrm{~cm}$ are year 1840 and 2010, respectively. While other stations on layer $3-4 \mathrm{~cm}$ and layer $0-1 \mathrm{~cm}$ are year 1965 and 2009 respectively. Therefore, it can be implied that sediment core at Station 1 is older than Station 2.

\section{Sediment deposition rate}

Sediment deposition rate is a sedimentation process that is caused by mechanical characteristics of suspended materials in the water or forming process and accumulating sediment in the bottom water. Result of this research reveals that depositing rate of sediment in each research station is commonly increasing year by year. Profile of sediment depositing rate towards ages of each depth at both stations, Station 1 and Station 2, are displayed in the following Figure 4.

Figure 4 shows that sediment depositing rate in Station 1 is about $0.08 \mathrm{~kg} \cdot \mathrm{m}^{-2} \cdot \mathrm{y}^{-1}$ (1840) or it is still happening since 175 years ago. Depositing sediment was still undergoing increase until year
2010 based on formula (iii) as $1.78 \mathrm{~kg} \cdot \mathrm{m}^{-2} \cdot \mathrm{y}^{-1}$. However, the depositing sediment of Station 2 is about 0.92 kg.m-2. $\mathrm{y}^{-1}$ (1965) or occurs since 50 years ago and the sediment process is still happening to increase until year 2009 or \pm 6 years and it achieves $3.31 \mathrm{~kg} \cdot \mathrm{m}^{-2} \cdot \mathrm{y}^{-1}$.

Origin of sediment particles from different areas is caused by different characteristics and distribution of sediment in certain location. Sediment depositing in different research location is happening in both locations. The Station 2 is mostly fine particles because it has relatively calm water movement and close to main sediment particle sources. However, the Station 1 is dominantly coarse particles because it has dynamical water circulation and faraway of sediment sources. Consequently, distributed particles have been dispersed widely. That is why this location has a lower sediment depositing rate than the Station 2. According to sea water current patterns (INDESO, 2015), sediment particle source at Station 2 is fathomed comes from main land, Western Borneo and Central Borneo, while sediment particle at Station 1 is supposed comes from Sumatera and Borneo because there is a meeting point of sea current from Borneo towards offshore (central Karimata Strait) and water circulation comes from Sumatera moving towards offshore. This condition happen either west monsoon or east monsoon. Beside current factor, it is affected by anthropogenic activities coming from main lands that give impact to increase mud particles.

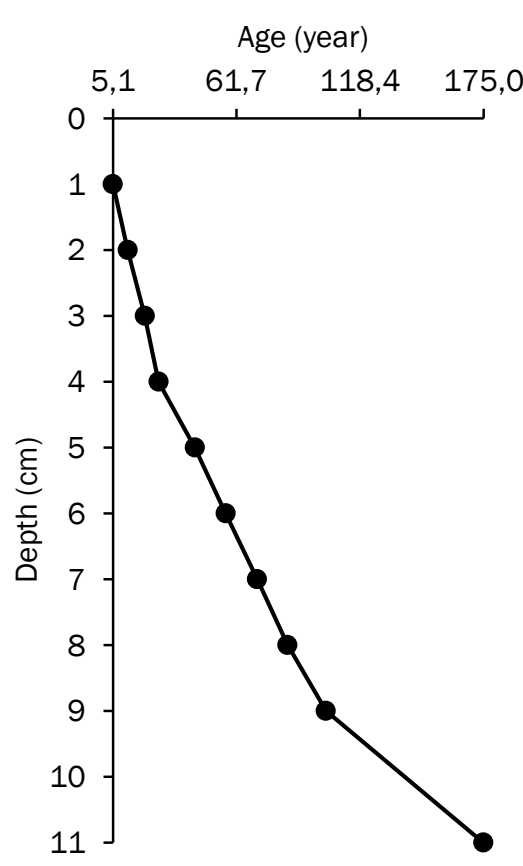

Station 1

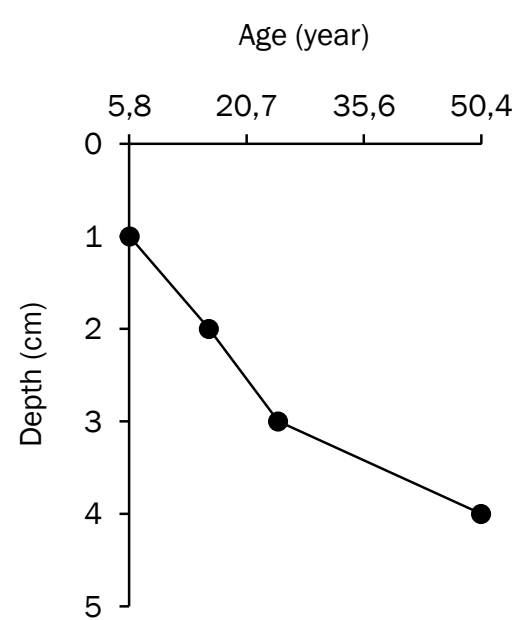

Station 2

Figure 3. Profile of Sediment Age Towards Depth at Karimata Strait 


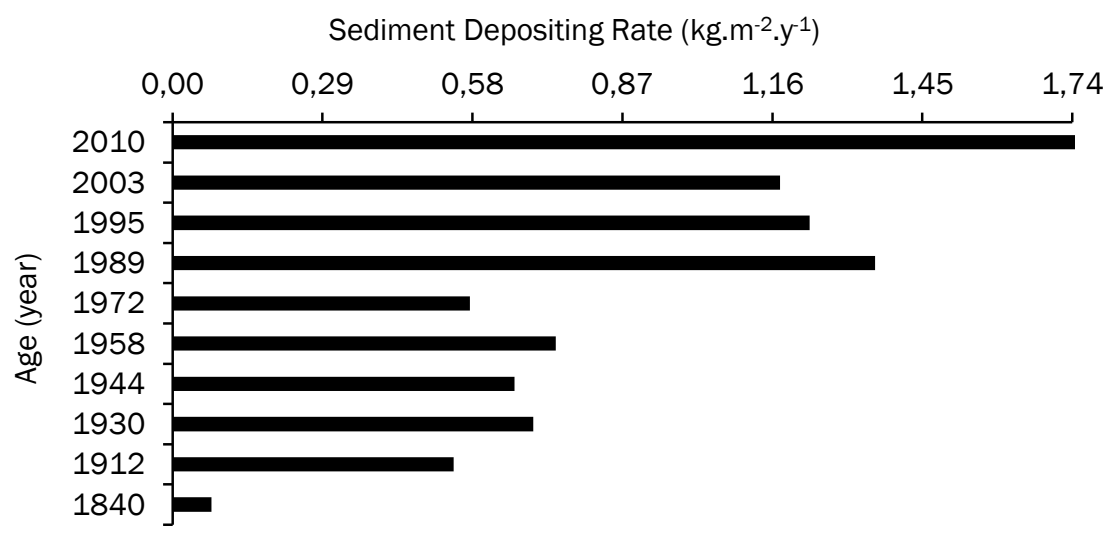

Station 1

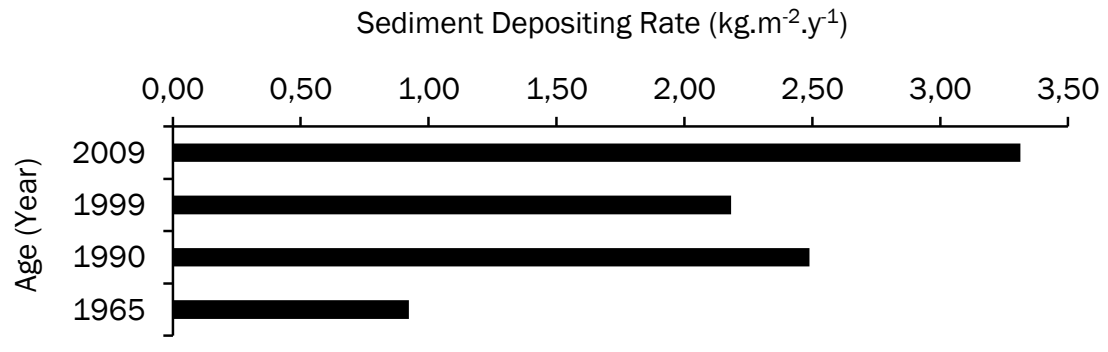

Station 2

Figure 4. Sediment Depositing Rate in Karimata Strait

Sediment depositing is highly correlated to sediment grain sizes. Beside this, speed of water current in a certain water also is playing an important role in the sediment depositing process. Those commonly particles in coarse size are deposited not faraway of its source location. Otherwise, the more fine of a particle size, the more faraway it is transported by current, so the more faraway depositing from its source. Sea water bottom sediment consists of different particle sizes and compositions. Coarse sediment fraction indicates highly hydrodynamics at the Station 1.

Sediment depositing rates in Karimata strait show various deposits. However, the strait is commonly undergoing increase until now, either near Western Borneo (Station 2) or offshore (Station 1). Different sediment depositing and sudden depositing changes as a result of extreme events such as floods, earthquakes, and tsunami (Tuttle, 2004; García-Orellana et al., 2006). One of an important factor also is a land use change in Borneo and Sumatera. This leads land cover of both island are still decreasing year by year specially forests. Study case in Watershed of Kapuas Hulu (Lusiana et al., 2008) revealed that land cover of forests decrease consecutively from year 2001-2004 are $9001 \mathrm{~km}^{2}$ to be $8873 \mathrm{~km}^{2}$.

Degradation of land covers especially in up streams and along river banks will cause river water debit increase and erosion along water banks. This condition also is followed by sediment particles input downwards to Karimata strait. BNPB Data (2016) several areas are categorized into prone to flooding in Indonesia such as West and Central Borneo, Belitung Island, Jambi and Riau. Number of flooding occurrences from 1979 to 2009 of those areas are73 times, 53 times, 6 times, 84 times and 2 times, respectively. This data can be an indicator that the main contributor of sediment particles coming from several rivers in Jambi, West Borneo and Central Borneo that all of those rivers terminate to Karimata strait.

\section{Conclusion}

Sediment depositing rate in Karimata Strait water shows the strait is still increasing years by years until now. Result of this research in the side of Borneo island has relatively low water circulation 
shows high sediment depositing rate than the offshore location which is open water and has more dynamic water condition.

\section{Acknowledgement}

Thanks to the Center of Radiation and Applied Isotope, National Nuclear Center of Indonesia (BATAN) at Lebak Bulus, South Jakarta that had been involved us into this collaborative research between BATAN and Ministry of Marine and Fisheries Affairs of Indonesia and used valuable laboratory facilities and equipment in completing this research.

\section{References}

Appleby, P.G. \& Oldfield, F. 1978.The calculation of ${ }^{210} \mathrm{~Pb}$ dates assuming a constant rate of supply of unsupported $210 \mathrm{~Pb}$ to the sediment. Catena 5(1):1-8. doi: 10.1016/S03418162 (78)80002-2

Badan Nasional Penanggulangan Bencana (BNPB). 2016. Peta kejadian bencana banjir di Indonesia tahun 1979-2009. www.bnpb.go.id

Ballestra, S. \& Hamilton, T. 1994. Basic Procedures Manual Radiochemistry, IAEA-Marine Environment Laboratory, Monaco. 75-79.

García-Orellana, J., Sanchez-Cabeza, J.A., Masqué, P., Avila, A., Costa, E., Loÿe-Pilot, M.D. \& Bruach-Menchén, J.M. 2006. Atmospheric fluxes of $210 \mathrm{~Pb}$ to the western Mediterranean Sea and the Saharan dust influence. J. Geophysic. Res. Atmosphere. 111(D15). doi: 10.1029/2005JD006660

Goldberg, E.D. 1963. Geochronology with $210 \mathrm{~Pb}$ in radioactive dating.Vienna: IAEA. 121-131.

Gordon, A.L., Susanto, R.D. \& Vranes, K. 2003. Cool Indonesian through flow as a consequence of restricted surface layer flow. Lett. Nature. 425:824-828. doi:10.1038/nature02038

Hancock, G.J. \& Hunter, J.R. 1999. Use of excess $210 \mathrm{~Pb}$ and $228 \mathrm{Th}$ to estimate rates of sediment accumulation and bioturbation in Port Phillip Bay, Australia.Mar. Freshwater Res. 50(6):533545. doi:10.1071/MF 98053

Infrastructure Development of Space Oceanography (INDESO). 2015. Data Model Pattern and Current Flow. INDESO [Internet]. [access 2016 May 27]. http://www.indeso.web.id/indeso_wp /index.php
International Atomic Energy Agency (IAEA)-1360. 2003. Collection and preparation of bottom sediment samples for analysis radionuclides and trace elements. Nutritional Health-Related Environ-mental Studies Section IAEA. Vienna, Austria.

Jeter, H.W. 2000. Determining the ages of recent sediments using measurements of trace radioactivity. Terra et Aqua. 78:21-28

Krishnaswamy, S., Lal, D., Martin, M. \& Meybeck, M. 1971. Geochronology of lake sediments. Earth Planetary Sci. Lett. 11(1-5):407-414. doi:10.10 16/0012-821X(71) 90202-0

Lubis AA, Aliyanta B, Menry Y. 2007. Estimation of Sediment Accumulation Rate in Jakarta Bay Using Natural Radionuclide Unsupported ${ }^{210} \mathrm{~Pb}$. Indo J Chem. 7(3):309-313.

Lubis, A.A. 2006. Constant Rate of Supply (CRS) Model for Determining the Sediment Accumulation Rate in the Coastal Area Using 210Pb. J.Coast Develop. 10(1):9-18.

Lusiana, B., Widodo, R., Mulyoutami, E., Adi, D.K. \& van Noordwijk, M. 2008. Kajian Kondisi Hidrologis DAS Kapuas Hulu, Kabupaten Kapuas Hulu, Kalimantan Barat. 79pp.

Rifardi, 2012. Ekologi Laut Modern. Riau. UR Press. $P: 13-15$.

Sanchez-Cabeza, J.A., Masque, P., Ragolta, A.I., Merino, J., Frignani, M., Alvisi, F., Palanques, A. $\&$ Puig, P. 1999. Sediment accumulation rates in the southern Barcelona continental margin (NW Mediterranean Sea) derived from ${ }^{210} \mathrm{~Pb}$ and ${ }^{137} \mathrm{Cs}$ chronology. Prog. Oceanography. 44(1-3):313-332. doi: 10.1016/S0079-6611 (99)00031-2

Situmorang, M. \& Andi S. 1999. Laporan Hasil Awal Survai Tindak Lanjut Penyelidikan Geologidan Geofisika Kelautan Lembar Peta 1413/1414, Perairan Sukadana, Ketapang, Kalimantan Barat, PPPGL.

Tuttle, M.P. 2004. Distinguishing tsunami deposits from storm deposits along the coast of northeastern North America: Lessons learned from the 1929 Grand Banks tsunami and the 1991 Halloween storm. Seismol. Res. Lett., 75:117-131.doi: 10.1785/gssrl.75.1.117

Willard, D.A., \& Holmes, C.W. 1997. Pollen and geochronological data from south Florida: Taylor Creek Site 2. US Geological Survey. 